\title{
Plasma Protein Cryoprecipitation
}

National Cancer Institute

\section{Source}

National Cancer Institute. Plasma Protein Cryoprecipitation. NCI Thesaurus. Code C112940.

A process to isolate plasma proteins by cooling the plasma to form a precipitate. 